\title{
Efficacy of a Lactoferrin-Penicillin Combination to Treat $\beta$-Lactam-Resistant Staphylococcus aureus Mastitis ${ }^{1}$
}

\author{
D. Petitclerc, ${ }^{\star 2}$ K. Lauzon, ${ }^{\star}$ A. Cochu, ${ }^{*}$ C. Ster, $\dagger$ M. S. Diarra, $\neq$ and P. Lacasse $†$ \\ ${ }^{*}$ Crea Biopharma Inc., Sherbrooke, Quebec, Canada J1E 4K8 \\ †Dairy and Swine Research and Development Centre, Agriculture and Agri-Food Canada, P.O. Box 90 STN Lennoxville, Sherbrooke, \\ Quebec, Canada J1M 1 Z3 \\ ¥Pacific Agri-Food Research Centre, Agriculture and Agri-Food Canada, P.O. Box 1000, Agassiz, British Columbia, Canada V0M 1A0
}

\begin{abstract}
The efficacy of intramammary (IM) treatments containing penicillin $\mathrm{G}(\mathrm{PG})$ alone or a combination of $\mathrm{PG}$ and bovine lactoferrin (bLF) was evaluated using a model of experimentally induced chronic bovine mastitis caused by a clinical isolate of Staphylococcus aureus highly resistant to $\beta$-lactam antibiotics. First, we confirmed that this strain could cause mastitis and infection could not be cured with PG alone. In a second trial, chronic mastitis was induced in 19 late-lactating cows by injecting a low dose of Staph. aureus through the teat canal of all quarters. After $15 \mathrm{~d}$, cows with stable infections in their 4 quarters had their mammary quarters randomly assigned, within cow, to 1 of 4 IM treatments as follows: 1) citrate buffer, 2) 100,000 IU of PG, (3) $1 \mathrm{~g}$ of bLF, or 4) $1 \mathrm{~g}$ of bLF + 100,000 IU of PG. Treatments were repeated twice a day for $5 \mathrm{~d}$. A third trial was undertaken to investigate the effect of an extended therapy on chronic mastitis acquired in a previous lactation. One month before dry-off, 20 gravid cows regrouped by dates of calving were infected in their 4 quarters. Once infections were established, cows were dried off abruptly. After calving, aseptic milk samples were collected separately from all quarters for $4 \mathrm{wk}$ to monitor infection. Mammary quarters from enrolled cows were then randomly assigned, within cow, to 1 of 2 treatments as follows: 1) $100,000 \mathrm{IU}$ of PG or 2) 250 $\mathrm{mg}$ of bLF $+100,000 \mathrm{IU}$ of PG. Treatments were administered IM twice a day for $7 \mathrm{~d}$. For all trials, milk samples were taken to monitor bacterial concentration and somatic cell count. Bacteriological cure rate was determined using milk samples taken 3 and 4 wk after initiation of treatments. For the second trial, cure rate was null for control quarters, $11.1 \%$ for bLF, $9.1 \%$ for PG,
\end{abstract}

\footnotetext{
Received September 14, 2006.

Accepted December 12, 2006.

${ }^{1}$ Dairy and Swine Research and Development Centre contribution no. 914.

${ }^{2}$ Corresponding author: denis.petitclerc@groupecrea.com
}

and $45.5 \%$ for the bLF + PG combination. For cows infected in their previous lactation, cure rate was higher for the bLF + PG combination (33.3\%) compared with PG alone (12.5\%). In conclusion, bLF added to PG is an effective combination (i.e., 3- to 5-times higher cure rate) for the treatment of stable Staph. aureu infections highly resistant to $\beta$-lactam antibiotics.

Key words: mammary gland, mastitis, bovine lactoferrin, $\beta$-lactam antibiotic

\section{INTRODUCTION}

Staphylococcus aureus and other staphylococcal species are major mastitis pathogens. During infection, Staph. aureus adheres to the glandular epithelium and causes erosion, which leads to local tissue invasion (Novick, 1990). Consequently, Staph. aureus mastitis is difficult to control by antibiotic treatment alone and requires aggressive culling of animals with refractory infection. In past decades, the widespread use of $\beta$ lactam antibiotics to treat bovine IMI has resulted in a striking increase of Staph. aureus strains resistant to these antibiotics (Watts and Salmon, 1997). The poor response of Staph. aureus mastitis to antibiotic therapy during lactation has been reported (Owens et al., 1997a; Wilson et al., 1999). In Staph. aureus strains, a common mechanism of resistance is the production of $\beta$-lactamases, which are enzymes that hydrolyze the $\beta$-lactam ring of penicillin and related antibiotics (Yao and Moellering, 1995). Indeed, Jones and Heath (1985) reported that $66.1 \%$ of Staph. aureus isolated from bovine IMI were $\beta$-lactamase-positive. Moreover, bacteriological cure rate of mastitis caused by $\beta$-lactamase-positive Staph. aureus is significantly less than those caused by $\beta$-lactamase-negative Staph. aureus (Sol et al., 2000).

Lactoferrin is an iron-binding glycoprotein naturally found in milk, bile, saliva, tears, and polymorphonuclear cell granules (Schanbacher et al., 1997). It has been shown that lactoferrin has bacteriostatic and bactericidal properties as well as immunomodulatory and anti-inflammatory activities (Rainard, 1993; Brock, 
1995). Using mastitis-causing Staph. aureus strains, Diarra et al. (2002) have shown in vitro that bovine lactoferrin (bLF) acted synergistically with penicillin G (PG) to decrease the MIC of PG and to reduce the growth of both $\beta$-lactam-sensitive and resistant strains of Staph. aureus. Additionally, bLF was reported to block the production of $\beta$-lactamase and some other exoproteins in Staph. aureus (Diarra et al., 2000). In fact, bLF can enhance several fold the growth inhibitory effects of numerous antibiotics including PG, ampicillin, novobiocin, erythromycin, and neomycin, especially against resistant strains (Diarra et al., 1999). Furthermore, it was also demonstrated that when combined with $P G, b L F$ reversed the negative effect of $P G$ on phagocytic activity of bovine polymorphonuclear leukocytes against Staph. aureus (Diarra et al., 2003b). Moreover, bLF alone or in combination with PG affect Staph. aureus aggregation and reduced invasion of mammary epithelial cells by Staph. aureus based on an in vitro epithelial invasion assay and an in vivo mouse model (Diarra et al., 2003a,b). Recently, Kai and coworkers (2002) demonstrated that infusion of bLF in nonlactating cows increased cure rate of staphylococcal mastitis. Hence, it is possible that exogenous infusion of bLF is useful for the treatment of bovine mastitis. The objective of this study was to investigate in dairy cattle the therapeutic potential of bLF + PG combinations to treat chronic mastitis caused by a strain of Staph. aureus highly resistant to $\beta$-lactam antibiotics.

\section{MATERIALS AND METHODS}

All experiments were approved by the Agriculture and Agri-Food Canada local institutional animal care committee and conducted in accordance with the guidelines of the Canadian Council on Animal Care. Animals were kept in a level 2 confinement barn at the Dairy and Swine Research and Development Centre for the entire duration of each trial.

\section{Bacteria}

The $\beta$-lactamase-producing strain, Staph. aureus SHY97-4320, used in the experiments presented below was a clinical isolate from a case of bovine mastitis infection previously described (Diarra et al., 2002). The MIC of antibiotics against this strain were as follows: ampicillin $(8 \mu \mathrm{g} / \mathrm{mL})$, amoxicillin $(64 \mu \mathrm{g} / \mathrm{mL})$, bLF $(\geq 51.2 \mathrm{mg} / \mathrm{mL})$, cefazolin $(1 \mu \mathrm{g} / \mathrm{mL})$, nisin A $(2.61 \mu \mathrm{g} /$ $\mathrm{mL}), \mathrm{PG}(32 \mu \mathrm{g} / \mathrm{mL})$, piperacillin $(64 \mu \mathrm{g} / \mathrm{mL})$, and tazo$\operatorname{bactam}(32 \mu \mathrm{g} / \mathrm{mL})$.

\section{Preparation of Bacterial Inocula}

Relationship Between Turbidity and Viable Count. Before each animal trial, the relation between optical density at $600 \mathrm{~nm}\left(\mathbf{O D}_{\mathbf{6 0 0 n m}}\right)$ and measured viable count was determined for the strain Staph. aureus SHY97-4320. A volume of $25 \mu \mathrm{L}$ of frozen bacterial stock $\left(-80^{\circ} \mathrm{C}\right)$ was plated on blood agar (tryptic soy agar $+5 \%$ sheep blood; Difco Laboratories, Detroit, MI) and incubated overnight at $37^{\circ} \mathrm{C}$ to verify purity. The next day, a single colony was used to inoculate $25 \mathrm{~mL}$ of fresh brain heart infusion broth (BHI, Difco Laboratories) and incubated overnight at $37^{\circ} \mathrm{C}$. The morning of the experiment, $100 \mu \mathrm{L}$ of this overnight culture of Staph. aureus in BHI was transferred to $100 \mathrm{~mL}$ of fresh BHI. The culture was incubated at $37^{\circ} \mathrm{C}$ for $9 \mathrm{~h}$ without shaking. Every hour, an aliquot was aseptically removed from the culture to 1) determine culture turbidity by measuring the $\mathrm{OD}_{600 \mathrm{~nm}}$ and 2) determine viable count. Viable count was measured by transferring $1 \mathrm{~mL}$ of bacteria solution in $9 \mathrm{~mL}$ of PBS-Tween (8.5 $\mathrm{g} / \mathrm{L}$ of $\mathrm{NaCl}, 2 \mathrm{~g} / \mathrm{L}$ of $\mathrm{K}_{2} \mathrm{HPO}_{4}, 1 \mathrm{~g} / \mathrm{L}$ of $\mathrm{KH}_{2} \mathrm{PO}_{4}, 5 \mathrm{~g} / \mathrm{L}$ of Tween 80). Solution was further serially diluted 10 fold and $100 \mu \mathrm{L}$ of each relevant dilution was plated on tryptic soy agar (TSA). Plates were incubated at $37^{\circ} \mathrm{C}$ for $24 \mathrm{~h}$ before determining the number of colonyforming units per milliliter. A standard curve $\left(\mathrm{OD}_{600}\right.$ nm vs. cfu count) was drawn from the results obtained. Each experiment was repeated twice.

Bacterial Suspension for Inoculation. The morning of the challenge, $0.5 \mathrm{~mL}$ of an overnight culture (BHI) of Staph. aureus SHY97-4320 was added to 10 $\mathrm{mL}$ of fresh $\mathrm{BHI}$ and grown at $37^{\circ} \mathrm{C}$ until $\mathrm{OD}_{600 \mathrm{~nm}}$ reaches 0.400 to 0.600 in the exponential growth phase. Bacteria were then centrifuged at 2,500 $\times g$ for $15 \mathrm{~min}$ and resuspended in sterile physiological saline (Baxter Healthcare Corporation, Deerfield, IL) before being centrifuged again for $20 \mathrm{~min}$ at $2,500 \times \mathrm{g}$. After 2 washes in physiological saline, the pellet was finally suspended in $5 \mathrm{~mL}$ of sterile physiological saline. An aliquot of the 5-mL suspension was used to determine bacterial concentration by using the relationship established between $\mathrm{OD}_{600 \mathrm{~nm}}$ and viability count. Accordingly, the bacterial suspension was further diluted in sterile saline to obtain the desired concentration of bacteria. Syringes were filled aseptically with $3 \mathrm{~mL}$ of bacterial solution and kept at $4^{\circ} \mathrm{C}$ until needed. Intramammary (IM) infusions were performed the same day immediately after p.m. milking. Each quarter was infused with $3 \mathrm{~mL}$ of bacterial suspension (see experiments 2 and 3 for specific concentrations). An aliquot of the diluted suspension was taken before and after infection to confirm viability of bacteria (i.e., cfu/mL). The aliquots were 10-fold serially diluted and plated on TSA (Difco) and incubated for $24 \mathrm{~h}$ at $37^{\circ} \mathrm{C}$.

\section{Intramammary Infusions}

Infusion of mammary quarter with bacteria, therapeutics, or both was performed according to the proce- 
dure described by Nickerson et al. (1999) with few modifications. All infusions were performed after milking. Before inoculation, the teat end of each enrolled quarter was thoroughly wiped to remove gross contamination and dipped in a solution of iodine. After a minimum of $30 \mathrm{~s}$ contact time, teats were wiped dry and subsequently scrubbed with gauzes soaked in $70 \%$ ethanol. Teats were allowed to air-dry. Foremilk was then discarded and IM infusion was performed. Immediately after, all quarters were thoroughly massaged and teats dipped again with an iodine solution. Disposable gloves were worn throughout the procedure and changed between each animal.

\section{Aseptic Milk Samples Collection and Determination of Bacterial Count}

Milk samples were always aseptically collected before milking using the procedure suggested by the National Mastitis Council (1996). After foremilk was discarded, a 10-mL milk sample was collected for each individual quarter in a $15 \mathrm{~mL}$ sterile tube. Milk samples were kept on ice before being stored at $-20^{\circ} \mathrm{C}$. Milk samples were thawed and plated in triplicates on TSA plates with a spiral plating system (Autoplate 4000, Spiral Biotech Inc., Norwood, MA) using "Uniform $250 \mu \mathrm{L}$ " and "Exponential $50 \mu \mathrm{L}$ " modes. Plates were then incubated 24 $\mathrm{h}$ at $37^{\circ} \mathrm{C}$ before colony count was obtained using an automated colony reader (QCount, Spiral Biotech Inc.).

\section{Preparation of Treatments}

All manipulations for the preparation of active ingredients solutions were performed under a biological cabinet. Penicillin G powder was bought from Novopharm Ltd. (Toronto, Ontario, Canada), and bLF was from DMV International (Veghel, The Netherlands). The amount of endotoxin per milligram of bLF did not exceed $0.2 \mathrm{ng}$. All solutions were prepared in sterile citrate buffer ( $1 \mathrm{~m} M$ citric acid, $10 \mathrm{~m} M$ sodium bicarbonate, $100 \mathrm{~m} M$ sodium chloride, $\mathrm{pH}$ 7.2) using sterile and lipopolysaccharide-free vessels. Stock solutions were prepared and kept frozen until used. Syringes with active ingredients were filled with $10 \mathrm{~mL}$ of thawed stock solutions 1 to $2 \mathrm{~h}$ prior to infusion and kept at $4^{\circ} \mathrm{C}$ until needed.

\section{Experiment 1: In Vivo Confirmation of Antibiotic Resistance}

Animal Conditioning and Experimental Procedures. For this preliminary experiment, a total of 28 quarters with confirmed mammary infections with PGresistant Staph. aureus SHY97-4320 (between $10^{3}$ and
$10^{4} \mathrm{cfu} / \mathrm{mL}$ ) were selected amongst 11 early lactating cows to initiate PG treatment. Mammary quarters were randomly assigned to 1 of 2 treatments to test resistance of bacteria to PG treatment: 250,000 IU of PG in $10 \mathrm{~mL}$ of commercial sterile saline or $500,000 \mathrm{IU}$ of $\mathrm{PG}$ in $10 \mathrm{~mL}$ of sterile saline. Intramammary treatments were initiated after the morning milking on $\mathrm{d} 0$ and repeated after each milking for 5 consecutive days (total of 10 doses). To determine bacterial load and response to treatment, aseptic milk samples were taken on d 0 , $1,2,3,4,6$, and 7 .

\section{Experiment 2: Effect of bLF-PG Combination in Late-Lactating Cows}

Nineteen late-lactating cows had all 4 mammary quarters individually inoculated (185 cfu) through the teat cistern with the PG-resistant Staph. aureus SHY97-4320 as described above. Aseptic milk samples were collected from all mammary quarters before and regularly after bacterial inoculation to monitor infection establishment and stability. Infections were allowed to stabilize for $15 \mathrm{~d}$ (between $10^{3}$ and $10^{4} \mathrm{cfu} / \mathrm{mL}$ ) before treatment initiation. Only cows with 4 infected quarters were allowed to enter the trial. Fifteen days after the initial infection, only 11 cows out of 19 had stable infection in their 4 quarters. Enrolled quarters were then randomly assigned, within cow, to 1 of 4 IM treatments as follows: 1) citrate buffer, 2) 100,000 IU of PG, 3) $1 \mathrm{~g}$ of bLF, or 4) $1 \mathrm{~g}$ of bLF + 100,000 IU of PG. All treatments were prepared in sterile citrate buffer to a final volume of $10 \mathrm{~mL}$ as described above. Intramammary treatments were initiated after the evening milking on $\mathrm{d} 0$ and repeated after each milking for 5 consecutive days (total of 10 doses). To determine bacterial load (cfu count), additional aseptic milk samples were taken during treatment period $(1,2,3$, and $5 \mathrm{~d}$ after initial infusion of treatments) and after cessation of treatments on $\mathrm{d} 7,13,20$, and 27 corresponding to $2,8,15$, and $22 \mathrm{~d}$ after cessation of treatment, respectively. Milk samples harvested before treatment initiation as well as on $\mathrm{d} 20$ and $27 \mathrm{~d}$ were sent for bacteriological analysis (Biovet Laboratory, St-Hyacinthe, QC, Canada). Variable number tandem repeats genotyping (selective primers kindly provided by F. Gilbert, INRA Laboratory, Tours, France) was performed as described by Gilbert et al. (2006) to ascertain the presence of specific Staph. aureus strain SHY97-4320. Each quarter was also monitored for SCC and milk lactose content.

\section{Experiment 3: Effect of a bLF-PG Combination in Chronically Infected Cows}

Animal Selection and Experimental Procedures. Twenty healthy Holstein cows in late lactation 
with bacteriologically negative milk samples and a milk SCC of less than $2 \times 10^{5}$ cells $/ \mathrm{mL}$ milk per individual quarter were selected for this study. Cows were all gravid and had expected dates of calving grouped within a 2-wk interval. Each individual mammary quarter was designated as an experimental unit. Thirty days before drying off, $3 \mathrm{~mL}$ of saline containing 100 cfu of Staph. aureus SHY97-4320 were infused into the teat cistern of each quarter as described above. Aseptic milk samples were collected from all mammary quarters before and regularly after bacterial inoculation to monitor infection establishment and stability. Quarters that were not infected were reinfected 1 wk after the initial infusion. Infections were allowed to stabilize (between $10^{3}$ and $10^{4} \mathrm{cfu} / \mathrm{mL}$ ) for 1 mo before cows were dried off abruptly. After all cows had calved, aseptic milk samples were collected independently from all quarters for $4 \mathrm{wk}$ to monitor infection pattern. Based on these results, 14 out of the 20 cows were enrolled in this experiment: 7 cows with all 4 quarters infected, 3 cows with 3 quarters infected, 4 cows with 2 quarters infected. Mammary quarters from experimental cows were randomly assigned, within cow, to 1 of 2 treatments as follows: 1) 100,000 IU of PG $(\mathrm{n}=20)$ or 2) 250 $\mathrm{mg}$ of bLF plus $100,000 \mathrm{IU}$ of PG $(\mathrm{n}=21) ; 4$ quarters were treated with saline only. All treatments were prepared in sterile citrate buffer with a final volume of $10 \mathrm{~mL}$ as described above. Intramammary treatments were initiated after the p.m. milking on $\mathrm{d} 0$ and repeated twice a day after each milking for 7 consecutive days (total of 14 doses). Aseptic milk samples were taken every day for $7 \mathrm{~d}$ during treatment period (d 1 to 7 ), and then $2,4,7,14,21$, and $28 \mathrm{~d}$ after cessation of treatment to determine milk bacterial concentration. Milk production, gross milk composition, and SCC of each quarter was also determined.

\section{Cure Rate Determination}

Bacteriological analysis (Biovet Laboratory) and PCR genotyping (Gilbert et al., 2006) were performed on samples taken prior to initiation of treatment and during wk 3 and 4 after initiation of treatment to ascertain the presence of the specific Staph. aureus SHY97-4320. Cure rate was also determined using samples taken 3 and $4 \mathrm{wk}$ after initiation of treatment. During routine bacteriological analysis, sterile milk samples were plated on TSA as a quality control, and $10 \%$ of these samples showed concentrations of $<10 \mathrm{cfu} / \mathrm{mL}$. Hence, based on this observation, we defined bacteriological cure rate as follows: if a cow had $0 \mathrm{cfu} / \mathrm{mL}$ in milk samples taken 3 and $4 \mathrm{wk}$ after onset of treatment and SCC less than 200,000 cells $/ \mathrm{mL}$, she was cured; if one sample had $0 \mathrm{cfu} / \mathrm{mL}$ and the second one less than 10

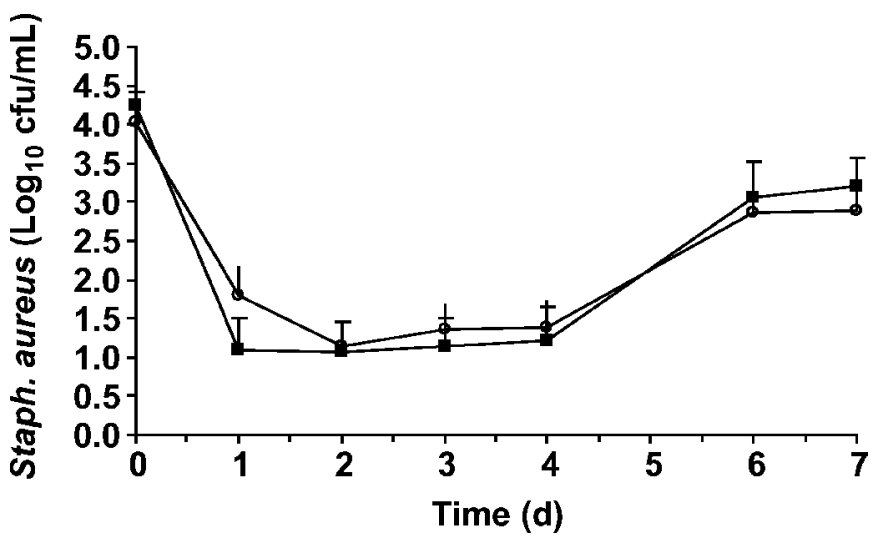

Figure 1. Comparison of 2 penicillin (PG) doses on $\beta$-lactamaseproducing Staphylococcus aureus SHY97-4320 shedding in milk from experimental infected quarters. Quarters were infused twice a day with $250,000 \mathrm{IU}(\bigcirc ; \mathrm{n}=14)$ or $500,000 \mathrm{IU}(\mathbf{\square} ; \mathrm{n}=14)$ of $\mathrm{PG}$ for 5 consecutive days. Day $0=$ time of the first intramammary infusions of treatments; data are presented as $\log _{10}$ transformed values \pm SEM.

cfu/mL with a SCC $<200,000$ cells $/ \mathrm{mL}$, she was considered cured if we could determine that she was not infected by Staph. aureus strain SHY97-4320 based on bacteriological evaluation and PCR analyses.

\section{Statistical Analysis}

The data were analyzed as repeated measurements using the MIXED procedure of SAS (SAS Institute, 2002) with spatial power as the covariance structure. For the second experiment, data were analyzed as a 2 $\times 2$ factorial design with levels of $P G$ and bLF as the main factors. The Tukey-Kramer posthoc test was used for pairwise comparisons. Because values were not normally distributed, statistical analysis of bacterial count was performed on the $\log _{10}$-transformed values. Association between cure rates and the 4 treatment combinations were tested with Fisher's exact test. Cure rates were also submitted to a logistic analysis using the LOGISTIC procedure of SAS with contrasts comparing each treatment combination to the control. Effects were considered significant at $P \leq 0.05$ and to tend to be significant at $0.05<P \leq 0.10$.

\section{RESULTS}

\section{Experiment 1: In Vivo Confirmation of Antibiotic Resistance}

The effect of IM infusion of PG on shedding of the $\beta$ lactamase-producing strain Staph. aureus SHY97-4320 is depicted in Figure 1. As early as one day after the first IM infusion, treatments with 250,000 or 500,000 IU reduced $(P<0.001)$ milk bacterial concentration 


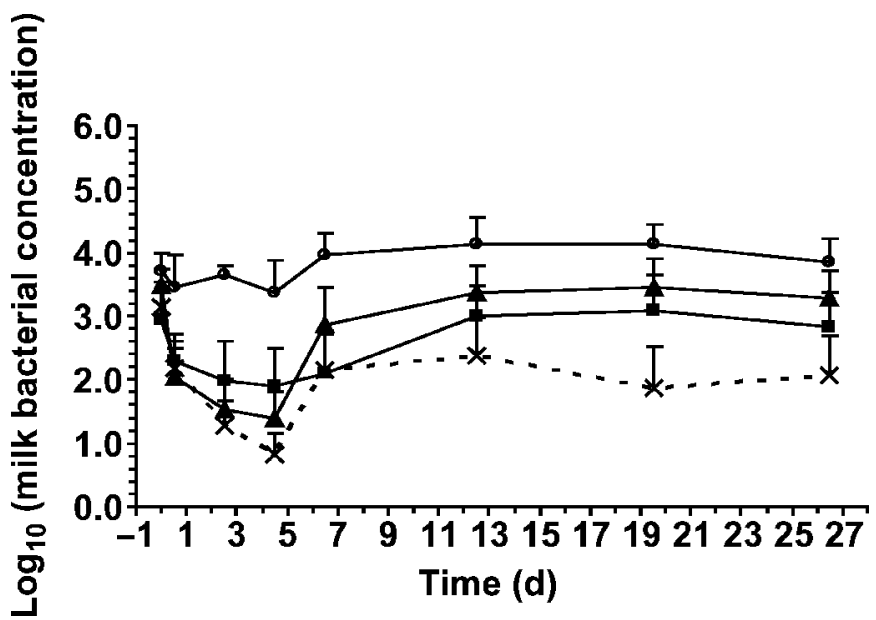

Figure 2. Effect of penicillin (PG), bovine lactoferrin (bLF), or both on bacterial concentration in milk from $14 \mathrm{~d}$ infected quarters by $\beta$-lactamase-producing Staphylococcus aureus SHY97-4320. Quarters were infused twice a day with citrate buffer $(O ; \mathrm{n}=11), 1 \mathrm{~g}$ of bLF $(\mathbf{\square} ; \mathrm{n}=9), 100,000 \mathrm{IU}$ of PG $(\boldsymbol{\Delta} ; \mathrm{n}=11)$, or bLF + PG $(\times ; \mathrm{n}=$ 11) for 5 consecutive days. Day $0=$ time of the first intramammary infusions of treatments; data are presented as $\log _{10}$ transformed values $\pm \mathrm{SEM}$.

down to $1.79 \pm 0.27$ and $1.09 \pm 0.37 \log _{10} \mathrm{cfu} / \mathrm{mL}$, respectively (Figure 1). For both PG concentrations, this effect was not enhanced $(P=0.57)$ by additional PG infusions because a plateau was reached and persisted throughout the treatment period. However, milk bacterial concentration increased rapidly after the cessation of treatment $(P<0.001)$, reaching $3.19 \pm 0.37$ or $2.89 \pm 0.36$ $\log _{10} \mathrm{cfu} / \mathrm{mL}$. For all time points, statistical analysis indicated no significant difference $(P>0.1)$ in efficacy of both PG treatments $(250,000$ vs. 500,000 IU) to reduce milk bacterial concentration.

\section{Experiment 2: Effect of a bLF-PG Combination in Late-Lactating Cows}

Intramammary infusion of Staph. aureus SHY974320 resulted in the expected inflammatory reactions as measured by standard diagnostic markers of mastitis. For all cows, IM infusion of Staph. aureus caused an increase in rectal temperature (from $38.5 \pm 0.3^{\circ} \mathrm{C}$ to $39.4 \pm 0.5^{\circ} \mathrm{C} ; P<0.001$ ) within $24 \mathrm{~h}$. Fifteen days after the initial infection, only 11 of 19 cows had stable subclinical infection in their 4 quarters as demonstrated by a milk bacterial count greater than $10^{3} \mathrm{cfu} / \mathrm{mL}$ in consecutive milk samples (data not shown).

The primary purpose of this trial was to compare bacterial cure rates of a traditional PG treatment with a novel approach that consisted of a combination of PG with bLF. Figure 2 depicts $\log _{10}$ bacterial number according to treatment over time. The number of bacte-

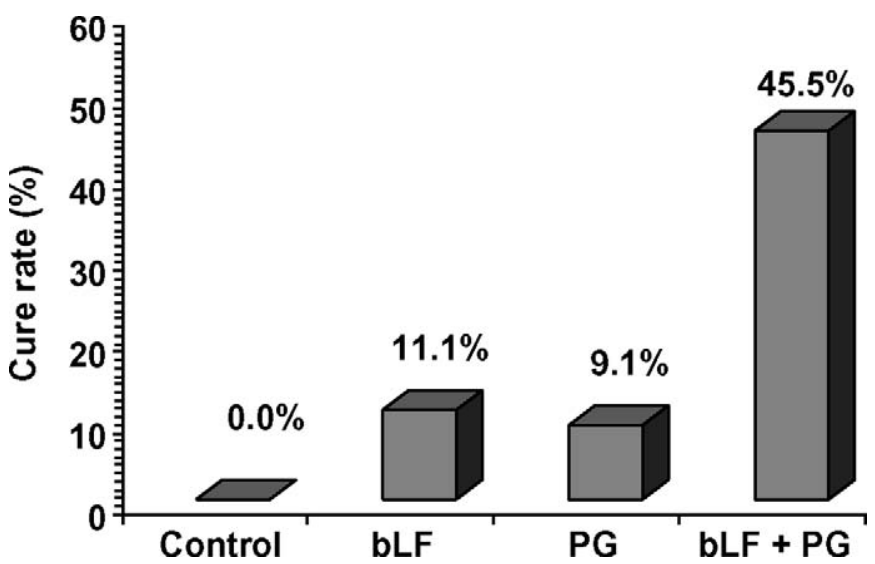

Figure 3. Cure rate of infected quarters by $\beta$-lactamase-producing Staphylococcus aureus SHY97-4320 in lactating cows after twice a day intramammary infusions for $5 \mathrm{~d}$ of citrate buffer (control; $\mathrm{n}=$ 11), $1 \mathrm{~g}$ of bovine lactoferrin ( $\mathrm{bLF} ; \mathrm{n}=9$ ), 100,000 IU of penicillin $\mathrm{G}$ (PG; $n=11)$, or the combination of $\mathrm{bLF}$ and $\mathrm{PG}(\mathrm{n}=11)$.

ria shed by control quarters remained stable for the whole period. During the treatment period, all quarters that received bLF, PG, or both had a significant decrease in milk bacterial count $(P<0.01)$ when compared with the control. Five days of treatment led to a $2,2.4$, and $3 \log$ reduction in bacterial number after treatment with PG, bLF and bLF + PG, respectively (Figure 2). However, as early as $2 \mathrm{~d}$ after the last treatment (d 7), the number of milk colony-forming units in quarters treated with PG or bLF alone were no longer different from their pretreatment concentrations $(P>0.10)$. In $\mathrm{bLF}+\mathrm{PG}$ treated cows, the bacterial number increase gradually but remained significantly lower $(P<0.05)$ on $\mathrm{d} 20$ and tended to be lower on d $27(P<0.1)$ when compared with the control and the 2 others treatments. A significant interaction between $\mathrm{PG}$ and bLF was present on $\mathrm{d} 3,5,7$, and $20(P<0.05)$, whereas only a tendency was pointed out on d $13(P=0.10)$ and 27 $(P=0.08)$.

Cure rate was null for control quarters whereas one quarter was considered cured in either bLF $(11.1 \%$; 1 out of 9$)$ or PG $(9.1 \%$; 1 out of 11$)$ treatments. In contrast, 5 of 11 quarters receiving the bLF + PG combination were completely cured from infection, resulting in a $45.5 \%$ cure rate (Figure 3 ). Fisher's exact test detected an association between treatments and cure rate $(P=$ $0.04)$. Even though the global effect was not significant in the logistic analysis $(P=0.18)$, comparison of each treatment to the control indicated that using both bLF and $P G$ results in better cure rate $(P=0.04)$. In fact, odds ratios were 7.3 when using both bLF and PG and 1.45 when using only 1 of the 2 treatments.

Before initiation of treatment, all quarters exhibited a high SCC, as showed in Figure 4A. During the treat- 

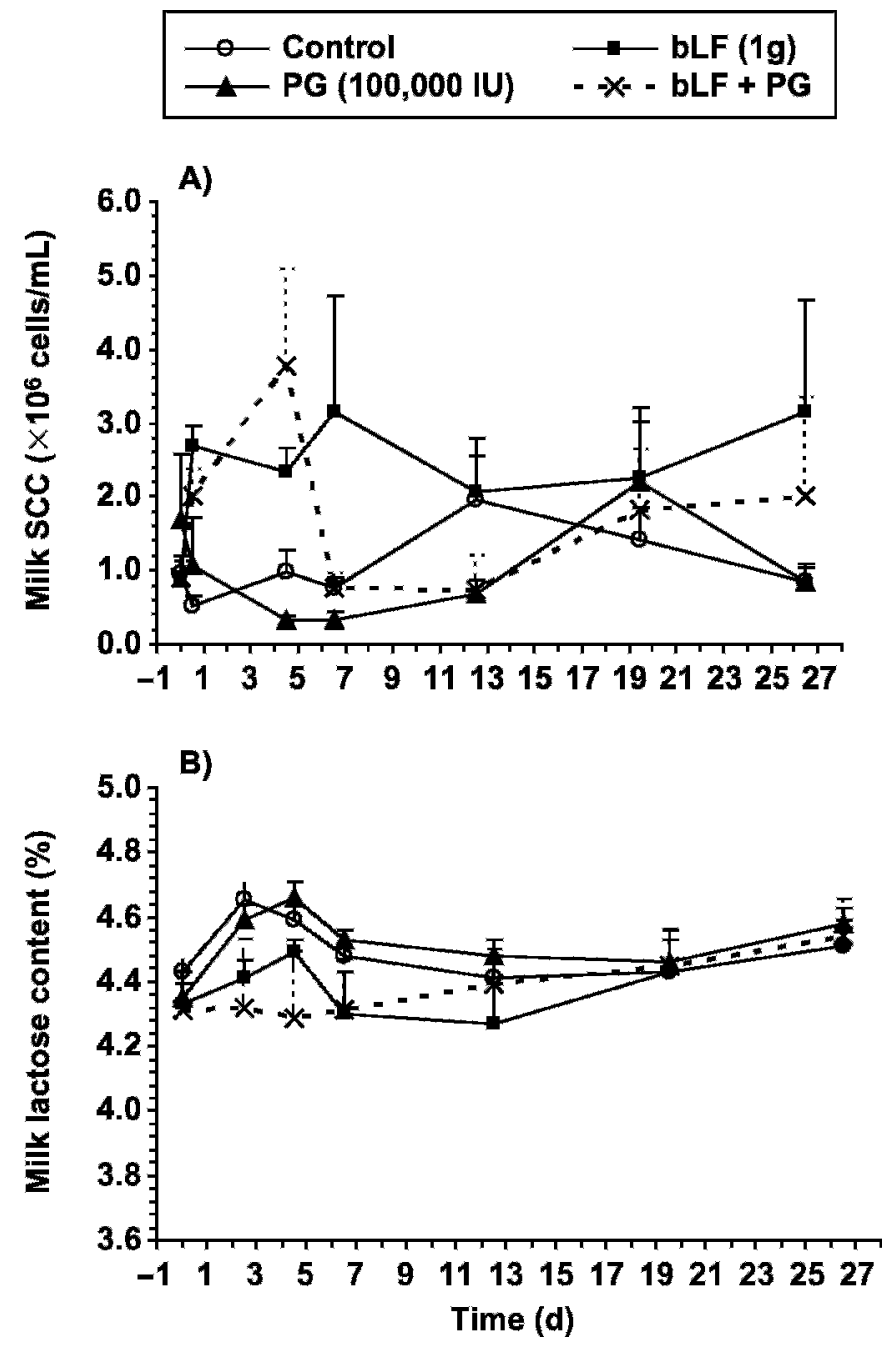

Figure 4. Effect of penicillin (PG), bovine lactoferrin (bLF), or both on A) SCC and B) lactose content in milk from 14-d infected quarters by $\beta$-lactamase-producing Staphylococcus aureus SHY974320. Quarters were infused twice a day with citrate buffer $(\bigcirc ; n=$ 11), $1 \mathrm{~g}$ of bovine lactoferrin (bLF; $\mathbf{\square} ; \mathrm{n}=9$ ), 100,000 IU of penicillin $\mathrm{G}(\mathrm{PG} ; \mathbf{\Delta} ; \mathrm{n}=11)$, or $\mathrm{bLF}+\mathrm{PG}(\times ; \mathrm{n}=11)$ for 5 consecutive days. Day $0=$ time of the first intramammary infusions of treatments; data are presented as $\log _{10}$ transformed values \pm SEM.

ment period (sampling d 1 to 5), infusion of PG alone did not modify average milk SCC $(P>0.05)$. However, there was a residual effect of PG to reduce SCC $2 \mathrm{~d}$ after cessation of treatments $(\mathrm{d} 7 ; P=0.05)$, whereas only a tendency was observed on d $13(P=0.07)$. This effect was lost thereafter $(P>0.1)$. On the other hand, infusion of bLF alone or in combination with PG increased the average milk SCC during treatment period ( $P=0.001$ and $P=0.003$, respectively). This effect remained $2 \mathrm{~d}$ after treatment interruption for either bLFor bLF + PG-treated quarters $(P=0.05$ and $P=0.03$, respectively) but it was lost thereafter $(P>0.1)$.
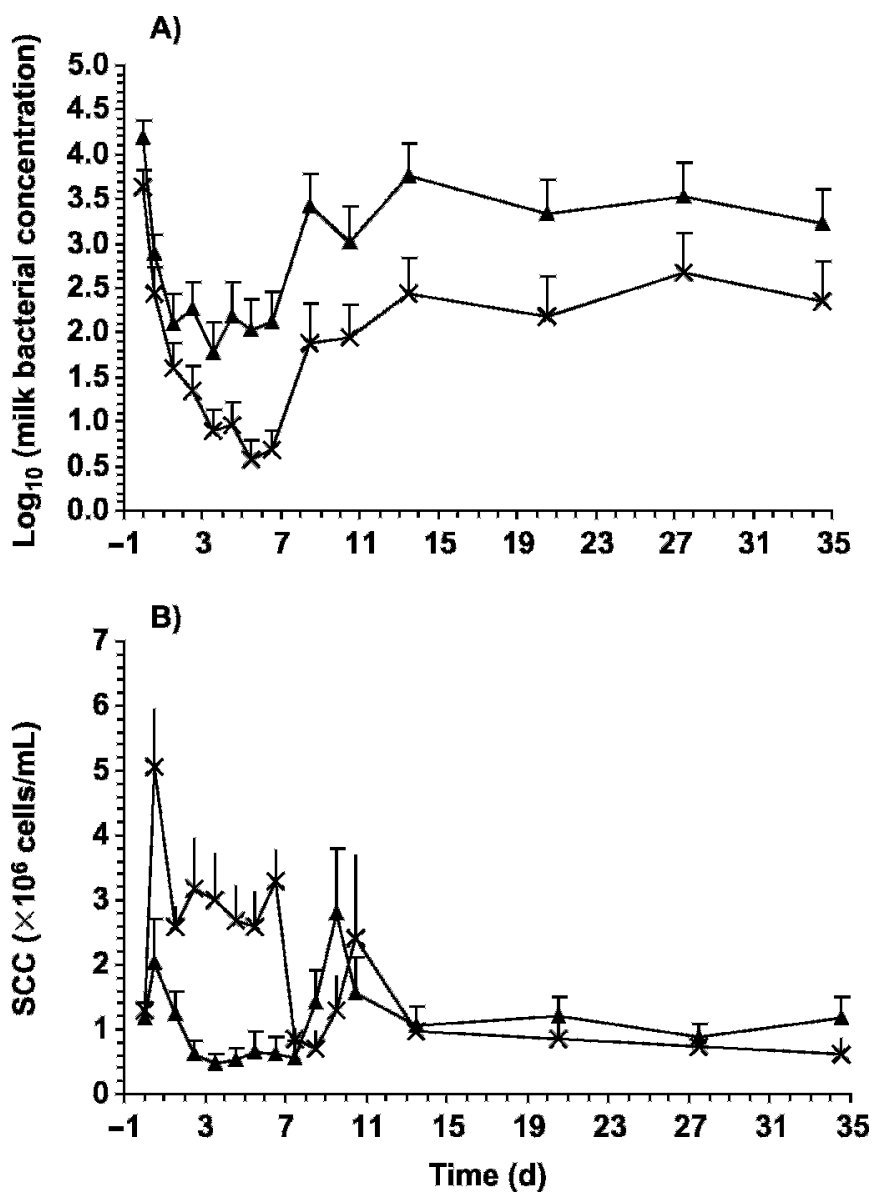

Figure 5. Effect of penicillin $\mathrm{G}(\mathrm{PG})$ or $\mathrm{PG}+$ bovine lactoferrin (bLF) on A) bacterial concentration and B) SCC in milk from quarters chronically infected by $\beta$-lactamase-producing Staphylococcus aureus SHY97-4320. Quarters were infused twice a day for 7 consecutive days with $100,000 \mathrm{IU}$ of PG $(\boldsymbol{\Delta} ; \mathrm{n}=20)$ or $250 \mathrm{mg}$ of bLF $+100,000$ IU of PG $(\times ; n=21)$. Day $0=$ time of the first intramammary infusions of treatments; data are presented as A) $\log _{10}$ transformed values \pm $\mathrm{SEM}$, and B) as unadjusted means \pm SEM.

Milk production was not affected by treatments $(P>$ 0.1 ; data not shown). All quarters had similar high milk lactose content before the beginning of the treatment period (Figure 4B). Intramammary infusion of PG did not affect milk lactose content $(P>0.1)$. Milk from quarters infused with bLF had smaller lactose content 3,5 , and $7 \mathrm{~d}$ after treatment initiation $(P<0.04)$. A significant interaction between bLF and PG on milk lactose content was present on $\mathrm{d} 3$ and $5(P=0.05$ and $P=$ 0.03 , respectively). Milk lactose was equivalent for all treatments for the rest of the trial.

\section{Experiment 3: Effect of a bLF-PG Combination in Chronically Infected Cows}

Figure 5A depicts $\log _{10}$ bacterial numbers according to treatment over time. Within $1 \mathrm{~d}$ of treatment, all 
quarters had a significant drop in milk bacterial count $(P<0.001)$. Treatment with bLF significantly enhanced the antimicrobial activity of PG $(P<0.01)$. Milk colonyforming unit concentrations of bLF + PG-treated quarters tended to be less (2.8 log decrease) than those of solely PG-treated (2.4 log decrease) quarters on d 3 ( $P=$ $0.09)$ and $4(P=0.10)$, whereas this effect was more pronounced on d $5(P=0.02), 5.5(P=0.007)$, and 7 $(P=0.009)$. On d 5 , treatment with bLF + PG led to a 3.6 log decrease in the bacterial number, whereas this decrease was 2.2 for bLF treatment. In both treatments, milk colony-forming unit concentrations started to increase $(P<0.001)$ after cessation of treatment. Thirtyfive days posttreatment, 2 of the PG treated quarters were considered cured, whereas 6 quarters were cured amongst those receiving the bLF + PG combination treatment, resulting in cure rates of 12.5 and $33.3 \%$, respectively; this difference was, however, not significant.

Before initiation of treatments, all quarters exhibited high SCC as shown in Figure 5B. Initiation of the combination treatment induced an immediate increase of SCC $(P<0.001)$ before decreasing the day after. During treatment period, SCC concentrations were higher in quarters receiving bLF $+\mathrm{PG}$ combination than those receiving $\mathrm{PG}$ alone $(P<0.01)$. This effect was totally lost $2 \mathrm{~d}$ after IM infusions were interrupted $(P=0.73)$.

\section{DISCUSSION}

Previous work had demonstrated that it is feasible to experimentally induce Staph. aureus mastitis by IM infusion (through the teat canal) of a small number of bacteria (Postle and Goodland, 1978). Accordingly, IM infusion of $\beta$-lactamase-producing Staph. aureus bacteria in our study was able to cause mastitis as evidenced by the recovery of viable bacteria in the milk and higher milk SCC comparable to concentrations reported by others (Haley et al., 1981; Sol et al., 2000). Furthermore, the antibiotic bacteriological response of mammary quarters infected with this clinical isolate of PG-resistant Staph. aureus SHY97-4320 was investigated. Our results clearly showed that PG alone (i.e., 250,000 and 500,000 IU per injection twice a day for $5 \mathrm{~d}$ ) was not efficient to treat this type of Staph. aureus infection. Indeed, during treatment a bacteriological response was observed, but a plateau was attained, confirming that this strain was capable of withstanding antibiotic therapy, and infection reemerged as soon as the therapy ended. Hence, we proceeded in subsequent experiments with this specific strain of Staph. aureus but with a reduced dose of PG (100,000 IU) per injection with or without bLF.
The efficacy of the bLF-PG combination has been demonstrated in vitro against resistant strains of Staph. aureus (Diarra et al., 2002), but no such evidence existed in vivo. Following treatment initiation, the significant drop in milk colony-forming units of quarters treated with bLF ( $1 \mathrm{~g}$ per injection in experiment 2 or $250 \mathrm{mg}$ per injection in experiment 3$)$ or PG $(100,000$ IU per injection in both experiments) unlike in control quarters confirmed that the 2 antimicrobial agents tested in this study had a certain antimicrobial effect on their own. On the other hand, when bLF and PG were combined, the drop in milk colony-forming units during treatment period was more pronounced, demonstrating a synergistic effect of bLF and PG as initially reported in vitro by Diarra et al. (2002). Moreover, after cessation of treatment, average bacterial concentrations of quarters treated with bLF or PG alone returned to pretreatment concentrations within $2 \mathrm{~d}$, whereas those of quarters treated with the combination remained smaller, indicating that quarters receiving this treatment combination were indeed cured from infection.

In staphylococcal mastitis, the ability of Staph. aureus to escape antibiotic therapy has been associated with the sequestration of bacteria in abscesses of mammary tissue (Gudding et al., 1983) as well as intracellular survival within the phagocytes (Craven and Anderson, 1980). To consider a quarter cured, it is recommended to have double-negative milk samples (Schukken and Deluyker, 1995) because Staph. aureus mastitis is known to show a cyclic rise and fall of detectable bacteria in the milk of infected glands (Daley et al., 1991). In these studies, bacteriological cure from infection was determined using samples taken 3 and 4 wk after initiation of treatments. Based on these samples, we observed, in experiments 2 and 3, a 3- to 5times higher cure rate for quarters treated with the combination of bLF and PG compared with quarters receiving $\mathrm{PG}$ alone. Moreover, in experiment 2, one quarter was not included in our cure rate because it had $0 \mathrm{cfu} / \mathrm{mL}$ on d 20 but $3 \mathrm{cfu} / \mathrm{mL}$ on d 27 with an SCC of 367,000 cells $/ \mathrm{mL}$. If this quarter were included, our cure rate for the bLF + PG combination would have been $55 \%$ for chronic IMI caused by a highly resistant $\beta$ lactamase-producing strain of Staph. aureus.

Overall bacteriological cure rates achieved in these experiments are highly significant. Indeed, Owens et al. (1997b) reported a cure rate of 35\% for chronic mastitis caused by PG-sensitive Staph. aureus and treated with a combination of $\mathrm{PG}$ procaine $(100,000 \mathrm{IU})$ and novobiocin (150 mg), which is currently approved commercially for the treatment of bovine IMI. Moreover, Oliver et al. (2004) used a new broad-spectrum, third-generation cephalosporin antibiotic (Ceftiofur) for veterinary use 
to treat subclinical mastitis and reported a cure rate of $36 \%$ for Staph. aureus after an extended therapy of $8 \mathrm{~d}$. Overall, although we have used a limited number of animals, our experiments have been performed with a highly resistant strain of Staph. aureus, and our results clearly demonstrate the efficacy of a bLF + PG combination, which is comparable to, if not better than, currently available products on the market. Furthermore, results obtained in experiment 3 with cows that had been infected in their previous lactation suggest that it is worthwhile to treat persistently infected cows, even in early lactation, instead of culling them.

The persistency of high SCC in milk as observed in our study was previously reported when mastitis was caused by $\beta$-lactamase-producing strains, which are associated with more chronic mastitis (Sol et al., 2000). Results from experiments 2 and 3 showed that during the treatment period, SCC in milk from quarters receiving bLF with or without PG exhibited an increase that was not visible in controls. It has been reported that $10 \mu \mathrm{g}$ of endotoxin infused into a mammary quarter could cause a mild to moderate inflammatory reaction (Anderson and Hunt, 1989). In our study, $1 \mathrm{~g}$ of bLF contained $0.2 \mu \mathrm{g}$ of endotoxin. Consequently, although it cannot be totally excluded that the low endotoxin content of bLF could be responsible for the increase of milk SCC, we think it is highly unlikely that this low amount of endotoxin would cause such a large rise in SCC. In fact, our observations would support the view that bLF may be active in modulation and regulation of macrophages, lymphocytes, and neutrophil function (Brock, 1995; Sordillo et al., 1997), thus attracting more neutrophils into the mammary gland.

Our results also showed a lesser milk lactose content in quarters infused with bLF compared to those not receiving bLF. However, no difference was observed in average milk production, even though lactose plays a key role as an osmotic regulator of milk volume (Pyorälä, 2003). On the other hand, the association between lactose and SCC is well known because neutrophil diapedesis into the mammary gland contributes to rupturing the blood-milk barrier, resulting in leakage of milk proteins and lactose toward the bloodstream (reviewed by Kitchen, 1981). Hence, the lesser lactose content observed in bLF-treated quarters may be associated with the important increase in SCC that occurred concomitantly in these quarters rather than being associated with a direct effect of bLF on lactose synthesis.

The exact mechanisms behind the superiority of the combination of bLF and PG over the use of PG alone are not fully elucidated and are probably multifactorial. However, we have reported that bLF inhibits mRNA expression of the gene responsible for the production of $\beta$-lactamase in Staph. aureus (Diarra et al., 1999), hence preventing degradation of PG. In addition, the ability of bLF to revert the negative effect of PG on phagocytosis has been previously demonstrated in vitro (Miyauchi et al., 1998) and also in vivo using a mouse mastitis model (Diarra et al., 2003b). Survival of Staph. aureus leading to therapy failure when PG is used has also been associated with a poor antibiotic penetration into the deep parenchymal tissue of the mammary gland (Owens and Nickerson, 1990). Whether bLF improves antibiotic distribution has not been investigated in this study. On the other hand, using an epithelial invasion assay, bLF alone or in combination with $\mathrm{PG}$ was shown to reduce invasion of mammary epithelial cells by Staph. aureus (Diarra et al., 2003b). Therefore, it is plausible that the relative efficacy of the bLF + PG combination used in this study results from a combination of these mechanisms, including the increase in neutrophil migration into the milk following bLF treatment in vivo. Furthermore, using a mouse infection model, we reported that $2 \mathrm{~d}$ of systemic treatments with bLF affected the morphology and aggregation of Staph. aureus, which may facilitate its killing by PG (Diarra et al., 2003a).

The bactericidal effect of $\beta$-lactam antibiotic is timedependent. Hence, for these antibiotics, the frequency of drug administration is an important determinant of the outcome of the IMI (Craig, 1993; Pyorälä, 2002) because the duration of time that serum concentrations of antibiotics exceed MIC is the major determinant of efficacy. Our results of bacterial disappearance support this view, because the lowest milk bacterial concentration was found after $5 \mathrm{~d}$ (experiment 2) and $7 \mathrm{~d}$ (experiment 3) of treatments. Accordingly, several authors suggested that a $3-d$ treatment might be too short a period to treat mastitis caused by $\beta$-lactamase-producing Staph. aureus and, therefore, will associate an extended therapy with an increased cure rate (Pyorälä and Mattila, 1987; Sol et al., 2000; Oliver et al., 2004).

Efficacy of treatment might be obtained by the use of commercial long-acting emulsions that improve the dispersion of bLF and PG into the mammary gland or by simultaneous systemic and IM therapy. Kutila et al. (2002) studied the disposition kinetics of bLF after IM administration of $1 \mathrm{~g}$ of bLF in aqueous solution; they observed that high bLF concentrations were maintained for several hours with a mean elimination halflife of $2.2 \mathrm{~h}$ and mean maximal concentration of 6,300 $\mu \mathrm{g} / \mathrm{mL}$. However, concentrations of bLF measured in milk exceeded the infusion concentration; Kutila et al. (2002) suggested that bLF being water-soluble, exogenous bLF did not spread throughout the infused quarter. Higher cure rates might also be achieved by a slightly higher dose of PG, inasmuch as it was demonstrated that the MIC of $\beta$-lactamase-positive strains in 
milk were 10- to 100-fold higher than those in broth (Ali-Vehmas et al., 1997). Moreover, Haley et al. (1981) reported that the maximum PG concentration reached in the milk when 100,000 IU was injected IM was 36.75 $\mathrm{IU} / \mathrm{mL}$. Knowing that the strain used in this study has a MIC for PG (in broth) of $51.2 \mathrm{IU} / \mathrm{mL}(32 \mu \mathrm{g} / \mathrm{mL})$, it is clear that the concentration of $P G$ reached in our experiments was under MIC. Moreover, the cows used in our studies had between 2 and 4 infected quarters, which made them more immunocompromised than cows with only one infected quarter. Finally, Sol et al. (1997) showed that the probability of cure with 2 or more infected quarters with Staph. aureus was smaller $(22.2 \%)$ than that of cows with only one infected quarter $(37.1 \%)$.

Treatment of chronic staphylococcal mastitis is clearly a problem. Once established, Staph. aureus mastitis usually does not respond to antibiotic treatment alone, especially if the strain involved produces $\beta$-lactamases. We have shown that IM therapy using a combination of bLF and PG could enhance significantly bacteriological cure rate compared with standard PG treatment. Moreover, our results clearly showed that an extended therapy for 5 to $7 \mathrm{~d}$ could contribute to bacterial clearance. Interestingly, bLF appeared to have a positive impact on neutrophil diapedesis toward the mammary gland.

In conclusion, bLF added to PG is an effective combination (i.e., 3- to 5-times higher cure rate) for the treatment of stable Staph. aureus infections highly resistant to $\beta$-lactam antibiotics. Still, the efficacy of this bLF + PG treatment combination could probably be enhanced by the use of a higher dose of PG. Furthermore, an optimized drug formulation would improve drug dispersion in milk and tissue, and thereby efficacy of this combination, following infusion into the mammary gland of infected cows.

\section{REFERENCES}

Ali-Vehmas, T., P. Westphalen, V. Myllys, and M. Sandholm. 1997. Binding of Staphylococcus aureus to milk fat globules increases resistance to penicillin-G. J. Dairy Res. 64:253-260.

Anderson, K. L., and E. Hunt. 1989. Anti-inflammatory therapy in acute endotoxin-induced bovine mastitis. Vet. Res. Commun. $13: 17-26$.

Brock, J. 1995. Lactoferrin: A multifunctional immunoregulatory protein? Immunol. Today 16:417-419.

Craig, W. 1993. Pharmacodynamics of antimicrobial agents as basis for determining dosage regimens. Eur. J. Clin. Microbiol. Infect. Dis. (Suppl. 1):6-8.

Craven, N., and J. C. Anderson. 1980. The effect of cloxacillin on staphylococci phagocytosed by bovine neutrophils. Res. Vet. Sci. 29:57-62.

Daley, M. J., P. A. Coyle, T. J. Williams, G. Furda, R. Dougherty, and P. W. Hayes. 1991. Staphylococcus aureus mastitis: Pathogenesis and treatment with bovine and interleukin- $1 \beta$ and interleukin2. J. Dairy Sci. 74:4413-4424.
Diarra, M. S., A. Cloutier, M. Perée, D. Petitclerc, and P. Lacasse. 2000 . Bovine lactoferrin affects growth, morphology and $\beta$-lactamase activity of $S$. aureus isolated from bovine mammary gland. Pages 188-190 in Proc. 39th Annu. Mtg. National Mastitis Council Inc., Atlanta, Georgia. National Mastitis Council, Madison, WI.

Diarra, M. S., P. Lacasse, G. Grondin, C. P. Bleau, and D. Petitclerc. 2003a. Ultrastructural and cytochemical study of cell wall modification by lactoferrin, lactoferricin and penicillin G against Staphylococcus aureus. J. Electr. Microsc. (Tokyo) 52:207-215.

Diarra, M. S., P. Lacasse, and D. Petitclerc. 1999. Method for treatment and/or prevention of antibiotic resistant microorganism infections. Assignee: Her Majesty the Queen in right of Canada. Patent no. PCT/CA00/01517.

Diarra, M. S., D. Petitclerc, E. Deschênes, N. Lessard, G. Grondin, B. G. Talbot, and P. Lacasse. 2003b. Lactoferrin against Staphylococcus aureus mastitis: Lactoferrin alone or in combination with penicillin $\mathrm{G}$ on bovine polymorphonuclear function and mammary epithelial cells colonization by Staphylococcus aureus. Vet. Immunol. Immunopathol. 95:33-42.

Diarra, M. S., D. Petitclerc, and P. Lacasse. 2002. Effect of lactoferrin in combination with penicillin on the morphology and the physiology of Staphylococcus aureus isolated from bovine mastitis. J. Dairy Sci. 85:1141-1149.

Gilbert, F. B., A. Fromageau, L. Gélineau, and B. Poutrel. 2006. Differentiation of bovine Staphylococcus aureus isolates by use of polymorphic tandem repeat typing. Vet. Microbiol. 117:297-303.

Gudding, R., J. McDonald, and N. F. Cheville. 1983. Pathogenesis of Staphylococcus aureus mastitis: Bacteriologic, histological, and ultrastructural pathologic findings. Am. J. Vet. Res. 45:25252531.

Haley, K., W. D. Black, and D. A. Barnum. 1981. Optimal milk penicillin levels for the treatment of experimentally induced mastitis in cows. Can. J. Comp. Med. 45:239-242.

Jones, T. O., and P. J. Heath. 1985. $\beta$-Lactamase production in Staphylococcus aureus isolated from bovine mastitis milk. Vet. Rec. 117:340.

Kai, K., Y. Komine, K. Komine, K. Asai, T. Kuroishi, T. Kozutsumi, M. Itagaki, M. Ohta, and K. Kumagai. 2002. Effects of bovine lactoferrin by the intramammary infusion in cows with staphylococcal mastitis during the early non-lactating period. J. Vet. Med. Sci. 64:873-878.

Kitchen, B. 1981. Review of the progress of dairy science: Bovine mastitis: Milk compositional changes and related diagnostic tests. J. Dairy Res. 48:167-188.

Kutila, T., S. Pyorälä, L. Kaartinen, K. Vahtola, L. Myllykoski, and H. Saloniemi. 2002. Disposition kinetics of lactoferrin in milk after intramammary administration. J. Vet. Pharmacol. Therap. 25:129-133.

Miyauchi, H., S. Hashimoto, M. Nakajima, I. Shinoda, Y. Fukuwatari, and H. Hayasawa. 1998. Bovine lactoferrin stimulates the phagocytic activity of human neutrophils: Identification of its active domain. Cell. Immunol. 187:34-37.

National Mastitis Council. 1996. Current Concept of Bovine Mastitis. 4th ed. National Mastitis Council, Madison, WI.

Nickerson, S. C., W. E. Owens, L. K. Fox, C. C. Scheifinger, T. R. Shryock, and T. E. Spike. 1999. Comparison of tilmicosin and cephapirin as therapeutics for Staphylococcus aureus mastitis at dry-off. J. Dairy Sci. 82:696-703.

Novick, R. P. 1990. Staphylococci. Pages 539-550 in Microbiology. 4th ed. B. D. Davis, ed. J. B. Lippincott Company, New York, NY.

Oliver, S. P., B. E. Gillespie, S. J. Headrick, H. Moorehead, P. Lunn, H. H. Dowlen, D. L. Johnson, K. C. Lamar, S. T. Chester, and W. M. Moseley. 2004. Efficacy of extended ceftiofur intramammary therapy for treatment of subclinical mastitis in lactating dairy cows. J. Dairy Sci. 87:2393-2400.

Owens, W. E., and S. C. Nickerson. 1990. Treatments of Staphylococcus aureus mastitis with penicillin and novobiocin: Antibiotic concentrations and bacteriological status in milk and mammary tissue. J. Dairy Sci. 73:115-124.

Owens, W. E., C. H. Ray, R. L. Boddie, and S. C. Nickerson. 1997a. Efficacy of sequential intramammary antibiotic treatment 
against chronic $S$. aureus intramammary infection. Large Anim. Pract. 5:10-14.

Owens, W. E., C. H. Ray, J. L. Watts, and R. J. Yancey. 1997b. Comparison of success of antibiotic therapy during lactation and results of antimicrobial susceptibility tests for bovine mastitis. J. Dairy Sci. 80:313-317.

Rainard P. 1993. Activation of the classical pathway of complement by binding of bovine lactoferrin to unencapsulated Streptococcus agalactiae. 79:648-652.

Postle, A. D., and F. C. Goodland. 1978. Comparison of three automated methods of serum tirglyceride analysis. Ann. Clin. Biochem. 15:18-24.

Pyorälä, S. 2002. Antimicrobial treatment of mastitis - Choice of the route of administration and efficacy. Pages 20-29 in Proc. Br. Mast. Conf., IAH and MDC, Brockworth, UK.

Pyorälä, S. 2003. Indicators of inflammation in the diagnosis of mastitis. Vet. Res. 34:565-578.

Pyorälä, S., and T. Mattila. 1987. Bovine acute mastitis. Part II Effect of mastitis pathogen, initial inflammatory reaction and therapy on the outcome of the disease. J. Vet. Med. B 34:629-639.

Rainard P. 1993. Activation of the classical pathway of complement by binding of bovine lactoferrin to unencapsulated Streptococcus agalactiae. Immunology 79:648-652.

Schanbacher, F. L., R. S. Talhouk, and F. A. Murray. 1997. Biology and origin of bioactive peptides in milk. Livest. Prod. Sci. 50:105-123.
Schukken, Y. H., and H. A. Deluyker. 1995. Design of field trials for the evaluation of antibacterial products for therapy of bovine clinical mastitis. J. Vet. Pharmacol. Therap. 18:274-283.

Sol, J., O. C. Sampimon, H. W. Barkema, and Y. H. Schukken. 2000. Factors associated with cure after therapy of clinical mastitis caused by Staphylococcus aureus. J. Dairy Sci. 83:278-284.

Sol, J., O. C. Sampinon, J. J. Snoep, and Y. H. Schukken. 1997. Factors associated with bacteriological cure during lactation after therapy for subclinical mastitis caused by Staphylococcus aureus. J. Dairy Sci. 80:2803-2808.

Sordillo, L. M., L. K. Shafer-Weaver, and D. DeRosa. 1997. Immunobiology of the mammary gland. J. Dairy Sci. 80:1851-1865.

SAS Institute. 2002. SAS User's Guide: Statistics. Release 9.1. ed. SAS Institute Inc., Cary, NC.

Watts, J. L., and S. A. Salmon. 1997. Activity of selected antimicrobial agents against strains of Staphylococcus aureus isolated from bovine intramammary infections that produce $\beta$-lactamase. J. Dairy Sci. 80:788-791.

Wilson, D. J., R. N. Gonzalez, K. L. Case, L. L. Garrison, and Y. T. Grohn. 1999. Comparison of seven antibiotic treatments with no treatment for bacteriological efficacy against bovine mastitis pathogens. J. Dairy Sci. 82:1664-1670.

Yao, J. D. C., and R. C. Moellering, Jr. 1995. Antibacterial agents. Page 1281 in Manual of Clinical Microbiology. 6th ed. P. R. Murray, E. J. Baron, M. A. Pfaller, F. C. Tenover, and R. H. Yolken, ed. Am. Soc. Microbiol., Washington, DC. 